\title{
Determination of The Physical, Physio-Chemical and Chemical Properties of Gilaburu Fruits (Viburnum opulus) Dried by Convectional Drying Technique ${ }^{\#}$
}

\begin{tabular}{|c|c|}
\hline \\
\hline \multicolumn{2}{|l|}{$\begin{array}{l}\text { Food Engineering Department, } \\
\text { Corresponding author } \\
\text { A R T I C L E I N F O }\end{array}$} \\
\hline $\begin{array}{l}\text { This study was presented as an online } \\
\text { resentation at the } 2^{\text {nd }} \text { International } \\
\text { ournal of Agriculture - Food Science } \\
\text { nd Technology (TURJAF 2021) } \\
\text { Fazimağusa/Cyprus } \\
\text { Research Article } \\
\text { Received : 01/12/2021 } \\
\text { Accepted : } 17 / 12 / 2021 \\
\text { Keywords: } \\
\text { Convectional drying } \\
\text { Temperature change } \\
\text { Total phenolic } \\
\text { Antioxidant activity } \\
\text { Texture }\end{array}$ & $\begin{array}{l}\text { f products in } \\
\text { ration caused } \\
\text { tional drying } \\
\text { ilaburu fruits } \\
\text { ectional oven } \\
n \text { the drying } \\
\text { creased with } \\
\text { uit }(\Delta \mathrm{E}) \text { was } \\
\text { ange. Similar } \\
\text { ible changes. } \\
\text { perties, skin- } \\
\text { creased with } \\
\text { es were also } \\
\text { temperature. }\end{array}$ \\
\hline
\end{tabular}

\section{Introduction}

Gilaburu fruit having valuable nutrients is processed to different food products such as fruit juice, nectar, vinegar, jam (Taşkın et al., 2019).

For longer shelf life of fruit and vegetable products, drying process has been used since ancient times due to its preservation effect against deterioration caused by microbial and/or biochemical changes (Alçay et al., 2015). Sun drying is one of the drying methods used by manufacturers. Besides of advantages like being low cost and practical application, this method leads to nutrient and quality losses in dried products (Midilli, 2001). Thus, producers focus on alternative ones. One of them and the most common one is the convectional drying in other words drying in a drying chamber under controlled hot air stream (Taşova et al., 2019). Convectional drying system consists of an oven equipped with a heater, a shielded impeller fan to distribute the hot air stream over single or more trays (Oliveira et al., 2016).

In this study, drying of Gilaburu fruits was aimed in a conventional oven at different temperature levels. Drying characteristics, the physical, physico-chemical and chemical properties of Gilaburu fruits were also investigated.

\section{Materials and Methods}

\section{Materials}

Gilaburu fruits used in this study were obtained from Kayseri. Fruits were harvested from plants in the same garden. Then, they were moved to laboratory of Food Engineering Department of Süleyman Demirel University and kept in a refrigerator until drying process.

\section{Drying Method}

Before drying process, Gilaburu fruits were washed and sorted to achieve uniform and homogeneous samples. For convectional drying processes, Mikrotest brand MKD-250 model tray-type drying oven equipped with a temperaturecontrolled was used. Drying processes were carried out at temperature levels of 60,70 and $80^{\circ} \mathrm{C}$. The mean air flow rate was $1.3 \mathrm{~m} / \mathrm{s}$ in drying chamber. Gilaburu fruits were speared as a single layer on a tray. Amount of sample used for each drying trial was constant and determined according to the system's capacity. During drying processes, moisture content of drying samples was monitored and process was finalized when sample's moisture content reduced below 15\% (Maisnam et al., 2017). Afterwards, dried gilaburu fruits were packed in a vacuum packaging material in a vacuum device (Vacuum 
Packaging Machine, DZ-350/MS, CHINA) and stored at $18^{\circ} \mathrm{C}$ until analysis.

\section{Color Measurement}

The color values of the dried samples were measured using a colorimeter (Model no: NH310, Portable Colorimeter, CHINA) and expressed as CIE $\left(L^{*}, a^{*}, b^{*}\right)$ color parameters (Keskin et al., 2017). Color measurement for each drying trial was carried on 10 dried samples and each was mean of the 3 locations of each one. Surface color change with drying process was evaluated compared to fresh Gilaburu fruit as a total color change $(\Delta \mathrm{E})$. Results were given as mean \pm standard error of all measurements for each drying trial.

\section{Rehydration Rate}

A fixed amount ( $4 \mathrm{~g}$ ) of dried sample was immersed in water at room temperature. For certain period, rehydrated samples were taken out and excess surface water was removed and samples were weighted and re-immersed in water (Khraisheh et al., 2004). Analysis was terminated when the weight of samples remained constant. The rehydration rate was calculated as the ratio of the final weight of the sample to its initial weight. The result for each drying trial was in the mean of three replicates.

\section{Titration Acidity}

For titration acidity, a fixed amount (4 g) of sample was homogenized in a fixed volume $(100 \mathrm{ml})$ of distilled water. It was then filtered through coarse filter paper. Filtrate was titrated with $0.1 \mathrm{~N} \mathrm{NaOH}$ and titration acidity of each sample was expressed in \% citric acid (Cemeroğlu, 2019).

\section{Solid/Liquid Extraction}

The solid/liquid ratio for the extraction process was $1 / 10(\mathrm{~g} / \mathrm{ml})$. The extraction solvent was pure methanol. Fruit samples and solvent were homogenized with UltraTurrax (IKA T18 basic, Germany) for 1 minute in a beaker. The homogenized solution was stirred on a magnetic stirrer at room temperature for 2 hours. After extraction, the liquid phase was separated from the solid sample phase by passing through filter paper, and then stored at $-18^{\circ} \mathrm{C}$ until analysis (Fang et al., 2002).

\section{Total Amount of Phenolic Compounds of Extracts}

The total amount of phenolic compounds of the extract was determined by using Folin-Ciocalteu spectrophotometric method developed by Singleton and Rossi (1965).

Briefly, $0.04 \mathrm{ml}$ of phenolic extract was mixed with 2.4 $\mathrm{ml}$ of deionized (DI) water and then $0.2 \mathrm{ml}$ of FolinCiocalteu reagent was added. After 5 minutes, $0.6 \mathrm{ml}$ of saturated $\mathrm{Na}_{2} \mathrm{CO}_{3}$ solution was added. The resulting mixture was left to stand for 2 hours for color development and absorbance at $765 \mathrm{~nm}$ was recorded using a spectrophotometer (T70+UV/VIS, PG Instruments, UK). Gallic acid was used as a standard to generate the calibration curve for quantification. Results were calculated as mg gallic acid equivalent per $\mathrm{g}$ dried matter.

\section{Antioxidant Activity of Extracts}

Antioxidant activity analysis was performed according to 2,2-diphenyl-1-picryl-hydrazil (DPPH) free radical scavenging activity assay (Dorman et al., 2003). Antioxidant activity of extracts from fresh and dried Gilaburu samples was measured as \% inhibition. Result was expressed as "mg trolox equivalent per g dry matter".

\section{Texture Analysis}

Skin hardness (g. force) and elasticity of dried products and fresh Gilaburu fruit were determined using a texture analyzer (TA-XT2 Texture Analyzer, Stable Microsystems, Godalming, UK) according to puncture test method. A $2 \mathrm{~mm}$ needle prob was used and prob speed was set as $1 \mathrm{~mm} / \mathrm{sec}$ (Barragán-Iglesias et al., 2019). Result was the mean of the corresponding textural values of three samples for each trial.

\section{Statistical Analysis}

Significant differences $(\mathrm{P}<0.05)$ between the means in the analysis data were evaluated with one-way ANOVA. Data were expressed as mean \pm standard error (Nunes et al., 2015). Statistical analysis was performed in Minitab version 17.1.0.

\section{Results and Discussion}

\section{Drying of Gilaburu Fruit by Convectional Drying}

Drying times were recorded for three different drying temperature values $\left(60,70\right.$ and $\left.80{ }^{\circ} \mathrm{C}\right)$ during convectional drying of Gilaburu fruit samples (Table 1). Drying time for Gilaburu fruits decreased with increasing temperature. Literature studies have also indicated the increase in drying rate and decrease in drying time with the increase in drying temperature (Kavak et al., 2006; Lee and Kim, 2009; Rafiee et al., 2010).

Table 1. Drying temperature and the corresponding drying time values

\begin{tabular}{l|c}
\hline \multicolumn{1}{c|}{ Drying } & Time \\
\hline $60^{\circ} \mathrm{C}$ & $2663 \mathrm{~min}$ \\
$70^{\circ} \mathrm{C}$ & $856 \mathrm{~min}$ \\
$80^{\circ} \mathrm{C}$ & $420 \mathrm{~min}$. \\
\hline
\end{tabular}

The favorable effect of temperature increase is related to heat and mass transfer phenomena taking place during drying. As temperature increased, temperature difference driving heat transfer increased and more energy was transferred to drying sample per unit time. As a result of more energy, the amount of water evaporated from the solid structure per unit time increased and drying was accelerated (Zhu and Shen, 2014). In addition, temperature dependent change in relative humidity of the drying air also affected mass transfer and thus drying rate (Masud et al., 2019). Increasing temperature decreased relative humidity of drying air, thus, water transfer from fruit materials to the air stream was accelerated.

\section{Color Value}

As a color parameter, total color change with respective to fresh fruit $(\Delta \mathrm{E})$ was examined. The calculated total color change values for corresponding drying trials were shown in Table 2. The results indicated that there was color change with drying, but irrespective of temperature value. Color change in Gilaburu fruits with drying was thought to 
be due to an adverse thermal effect on color pigments and also resulting enzymatic and none-enzymatic reactions (Skrede et al., 2000).

In a study in which hot air drying of food materials was examined at different temperatures, it was reported that color losses at low air velocity were caused by prolonged drying time (Tontul et al., 2019). Zielinska et al. (2016) have studied the drying of blueberries and reported similar results to present ones. In that study, it was observed that convectional drying produced dehydrated samples with great overall change in color values depending on temperature level and the most significant change in color attributes was determined for drying trial at $60^{\circ} \mathrm{C}$.

\section{Rehydration Rates}

Rehydration rates of dried food materials are widely used as a quality index (Qing-guo et al., 2007). Rehydration results were given in Table 2. Drying temperature did not create any effect on rehydration ratio of dried samples. In other words, it can be concluded that there is no significant difference between total color changes of dried samples depending on processes temperature in the studied range $(\mathrm{P}>0.05)$.

\section{Texture}

Skin-hardness values of fresh and dried Gilaburus at different temperature levels were measured and results were given in Table 3. It was observed that the skinhardness values of dried products increased with an increase in drying temperature. It was associated with case hardening on fruit surface layer which gets stronger with temperature increase as a result of accelerated moisture transfer. Similarly, Zielinska et al. (2016) showed that the hardness of dried blueberries increased with convective drying at elevated temperature levels, and reported the highest hardness value for drying at $80^{\circ} \mathrm{C}$. This temperature dependent change was explained with structural changes in fruit matrix. It was said that the highest values of hardness convectional drying at $80^{\circ} \mathrm{C}$ could be attributed to the presence of a thick surface layer. Furthermore, they have discussed that higher water vapor pressure inside the sample at elevated temperature levels resulted in an accumulation of flesh under the skin which is the main reason for higher hardness values. Elasticity values of fresh and dry Gilaburus at different temperature levels of conventional drying were measured and given in Table 3. The results indicated that an increase in drying temperature caused a decreasing elasticity of fruit samples. This was thought to be related to structural changes which occur during drying process and get stronger with elevating temperature as a result of increasing crispness depending on moisture removal.

\section{Titration Acidity and $\mathrm{pH}$}

In this study titration acidity (\%) and $\mathrm{pH}$ values of fresh and dried Gilaburu samples were examined to determine the effect of conventional drying process carried out at different temperatures. The measured results were shown in Table 3. It was determined that the titration acidity values increased with drying process due to the proportional change in organic acid content as a result of moisture removal. It can be seen that there is no any strong variation in titration acidity (\%) of dried samples depending on temperature level. However, compared to that value for samples dried at $80^{\circ} \mathrm{C}$, it was found lower for dried samples obtained at $60^{\circ} \mathrm{C}$. Khiari et al. (2019) also reported that a decrease in titratable acidity of dried raisin was favored by low air dehydration temperature and long process time. Being coincidence with titration acidity results, $\mathrm{pH}$ values for corresponding drying trials displayed similar variation trends compared to fresh one and there was no any significant difference in between each other.

\section{Total Amount of Phenolic Compounds}

Total amount of phenolic compounds of fresh Gilaburu fruits and dried ones at different drying temperatures were determined and given in Table 4.

In convectional drying, an increase in the total phenolic content was observed with the shortening of the process time as a result of temperature elevation. It is thought that phenolic compounds of dried fruits were protected from thermal damage due to less exposure time to severe heating effect as a result of accelerated drying process with temperature increase.

Table 2. $\Delta \mathrm{E}$ and rehydration rate values of dried Gilaburu fruits

\begin{tabular}{l|cc}
\hline \multicolumn{1}{c|}{ Drying } & $\Delta$ E Values & Rehydration Rates \\
\hline $60^{\circ} \mathrm{C}$ & $11.70 \pm 0.79^{\mathrm{a}}$ & $2.76 \pm 0.054^{\mathrm{a}}$ \\
$70^{\circ} \mathrm{C}$ & $9.97 \pm 1.11^{\mathrm{a}}$ & $2.89 \pm 0.173^{\mathrm{a}}$ \\
$80^{\circ} \mathrm{C}$ & $10.23 \pm 0.825^{\mathrm{a}}$ & $2.90 \pm 0.026^{\mathrm{a}}$ \\
\hline
\end{tabular}

Table 3. Textural properties, titration acidity $(\%)$, and $\mathrm{pH}$ values of fresh and dried Gilaburu fruits

\begin{tabular}{l|cccc}
\hline \multicolumn{1}{c}{ Drying } & Skin-hardness Values $(\mathrm{g})$ & Elasticity Values $(\mathrm{mm})$ & Titration Acidity $(\%)$ Values & $\mathrm{pH}$ Values \\
\hline $60^{\circ} \mathrm{C}$ & $652 \pm 264^{\mathrm{a} . \mathrm{b}}$ & $2.86 \pm 0.154^{\mathrm{b}}$ & $6.49 \pm 0.032^{\mathrm{b}}$ & $3.27 \pm 0.01^{\mathrm{b}}$ \\
$70^{\circ} \mathrm{C}$ & $687 \pm 195^{\mathrm{a} . \mathrm{b}}$ & $2.78 \pm 0.126^{\mathrm{b}}$ & $6.89 \pm 0.168^{\mathrm{a}}$ & $3.25 \pm 0.005^{\mathrm{b} . \mathrm{c}}$ \\
$80^{\circ} \mathrm{C}$ & $959 \pm 138^{\mathrm{a}}$ & $2.35 \pm 0.104^{\mathrm{c}}$ & $6.81 \pm 0.082^{\mathrm{a} . \mathrm{b}}$ & $3.22 \pm 0.02^{\mathrm{c}}$ \\
Fresh Fruit & $325.3 \pm 27.4^{\mathrm{b}}$ & $4.38 \pm 0.139^{\mathrm{a}}$ & $1.06 \pm 0.011^{\mathrm{c}}$ & $3.61 \pm 0.005^{\mathrm{a}}$ \\
\hline
\end{tabular}

Table 4. Total amount of phenolic compounds and antioxidant activity values of fresh and dried Gilaburu fruits

\begin{tabular}{l|cc}
\hline \multicolumn{1}{c|}{ Drying } & Total Phenolic Compounds (mg GAE g-1 DM) & Antioxidant Activity (mg TE g-1 DM) \\
\hline $60{ }^{\circ} \mathrm{C}$ & $35.31 \pm 2.45^{\mathrm{b}}$ & $72.77 \pm 0.775^{\mathrm{c}}$ \\
$70{ }^{\circ} \mathrm{C}$ & $38.18 \pm 1.61^{\mathrm{a} . \mathrm{b}}$ & $83.33 \pm 0.182^{\mathrm{b}}$ \\
$80{ }^{\circ} \mathrm{C}$ & $40.95 \pm 2.12^{\mathrm{a} . \mathrm{b}}$ & $95.06 \pm 2.55^{\mathrm{a}}$ \\
Fresh Fruit & $45.46 \pm 2.86^{\mathrm{a}}$ & $55.25 \pm 2.64^{\mathrm{d}}$ \\
\hline
\end{tabular}


There are different studies in the literature that support our results. For example, in a study about cranberry drying, the loss of total phenolic content in samples dried at $50^{\circ} \mathrm{C}$, $60^{\circ} \mathrm{C}$ and $70^{\circ} \mathrm{C}$ compared to fresh fruit was determined to be $51.25 \%, 47.13$ and $38.56 \%$, respectively. It has been reported that the reason for the total phenolic loss being higher for drying at $50{ }^{\circ} \mathrm{C}$ than that at $70^{\circ} \mathrm{C}$ is due to longer exposure time heat (Demir et al., 2019). It has been also reported in the literature that heat treatment can increase the digestibility of foods and allow active ingredients to be dissolved and released from foods more easily. Additionally, it has been stated that prolonged heat treatment may cause degradation or chemical reactions of active substances, thereby reducing their effective concentration (Wang et al., 2019).

\section{Antioxidant Activity}

Antioxidant activity values of fresh Gilaburus and dried Gilaburus obtained at different drying temperatures were calculated on $\mathrm{mg} / \mathrm{g}$ dry matter, in terms of trolox equivalent. All calculated values were given in Table 4. In convectional drying, it was observed that there was a decrease in antioxidant activity with an increase in the drying time of Gilaburu fruits. It is known that there is a strong relation between phenolic content of food material and its antioxidant activity. Therefore, it was thought that a decrease in antioxidant activity was detected in dried fruit samples as a result of phenolic loss depending on processing conditions. It can also be seen from Table 4 , there is a strong relation between phenolic content and antioxidant activity for our results. Maillard reactions, progressing especially under high temperature treatments, cause higher antioxidant activity of food materials due to its products. In our study one part of an increase in antioxidant activity with temperature elevation may be associated with this Maillard reaction's products.

Lower antioxidant activity value for fresh Gilaburu fruit was obtained compared to all dried samples. This can be attributed to the easier dissolution of the active compounds in the extraction solvent and faster release from the food matrix under the influence of heat during the drying process. In addition, it has been reported that Maillard reaction's products produced especially during high temperature heat treatments are also effective in increasing antioxidant activity values (Tan et al., 2013). This does not applicable for fresh samples.

\section{Conclusion}

Within the scope of our study, the effects of convectional drying method at different temperatures on the drying time and quality of Gilaburu fruit were determined. Convectional drying was carried out at temperatures of 60,70 and $80{ }^{\circ} \mathrm{C}$. It cannot be found any significant change in most of the studied physical properties except for skin-hardness and elasticity. Textural properties altered with drying, as skin hardness increased, elasticity decreased. On contrary, content of bioactive compounds and their functionality varied in wide extent with drying conditions. As a conclusion drying at moderate temperature levels resulted in dried Gilaburu fruits with better textural properties, although their functionality was lower than and other physical properties (color change, rehydration ratio) were identical to dried samples at higher drying temperatures.

\section{Acknowledgements}

This research has been financially supported by Süleyman Demirel University Scientific Research Projects Unit under the project number FYL-2020-8290.

\section{References}

Alçay AÜ, Yalçın S, Bostan K, Dinçel E. 2015. Orta Asya'dan Anadolu'ya Kurutulmuş Gidalar. ABMYO Journal, 40: 8393.

Barragán-Iglesias J, Rodríguez-Ramírez J, Sablani SS, MéndezLagunas LL. 2019. Texture analysis of dried papaya (Carica papaya L., cv. Maradol) pretreated with calcium and osmotic dehydration. Drying Technology, 37(7): 906-919. doi:10.1080/07373937.2018.1473420

Cemeroğlu BS. 2019. Gida Analizleri. Talebe Publications, 508p., Ankara.

Demir H, Atalay D, Erge HS. 2019. Kinetics of the Changes in Bio-Active Compounds, Antioxidant Capacity and Color of Cornelian Cherries Dried at Different Temperatures. Journal of Food Measurement and Characterization, 13(3): 20322040.

Dorman HJD, Peltoketo A, Hiltunen R, Tikkanen MJ. 2003. Characterization of the Antioxidant Properties of DeOdourised Aqueous Extracts from Selected Lamiaceae Herbs, Food Chemistry, 83 (2): 255-262.

Fang N, Yu S, Prior RL. 2002. LC/MS/MS characterization of phenolic constituents in dried plums. Journal of Agricultural and Food Chemistry, 50(12): 3579-3585. doi:10.1021/jf0201327

Kavak E, Bicer Y, Cetinkaya F. 2006. Modelling of Thin Layer Drying of Parsley Leaves in A Convective Dryer and Under Open Sun. Journal of Food Engineering, 75(3): 308-315.

Keskin M, Setlek P, Demir S. 2017. Renk Ölçüm Sistemlerinin Gida Bilimleri ve Tarım da Kullanım Alanları. Osmaniye, Turkey, 16-18 November 2017, International Advanced Researches \& Engineering Congress, 2350-2359.

Khiari R, Zemni H, Mihoubi D. 2019. Raisin processing: physicochemical, nutritional and microbiological quality characteristics as affected by drying process. Food Reviews $\begin{array}{lll}\text { International, } & 35(3): & 246-298 .\end{array}$ doi:10.1080/87559129.2018.1517264

Khraisheh MAM, McMinn WAM, Magee TRA. 2004. Quality and Structural Changes in Starchy Foods During Microwave and Convective Drying. Food Research International, 37: 497-503.

Lee JH, Kim HJ. 2009. Vacuum Drying Kinetics of Asian White Radish (Raphanus Sativus L.) Slices. LWT - Food Science and Technology, 42(1): 180-186.

Maisnam D, Rasane P, Dey A, Kaur S, Sarma C. 2017. Recent advances in conventional drying of foods : a review. J Food Technol Pres., 1(1): 25-34.

Masud MH, Joardder MUH, Karim, MA. 2019. Effect of Hysteresis Phenomena of Cellular Plant-Based Food Materials on Convection Drying Kinetics. Drying Technology, 37(10): 1313-1320.

Midilli A. 2001. Determination of Pistachio Drying Behaviour and Conditions in A Solar Drying System. International Journal of Energy Research, 25: 715-725.

Nunes CA, Alvarenga VO, Sant'Ana AS, Santos JS, Granato D. 2015. The use of statistical software in food science and technology: Advantages, limitations and misuses. Food Research International, 75: 270-280. doi:10.1016/j.foodres.2015.06.011 
Oliveira SM, Brandao TRS, Silva CLM. 2016. Influence of Drying Processes and Pretreatments on Nutritional and Bioactive Characteristics of Dried Vegetables: A Review. Food Engineering Reviews, 8: 134-163.

Qing-guo H, Min Z, Mujumdar AS, Wei-hua D, Jin-cai S. 2006. Effects of Different Drying Methods On The Quality Changes of Granular Edamame. Drying Technology, 24(8): 10251032.

Rafiee S, Sharifi M, Keyhani A, Omid M, Jafari A, Mohtasebi SS, Mobli H. 2010. Modeling Effective Moisture Diffusivity of Orange Slice (Thompson Cv.). International Journal of Food Properties, 13(1): 32-40.

Singleton VL, Rossi JA. 1965. Colorimetry of Total Phenolics with Phosphomolybdic-Phosphotungstic Acid Reagents. American Journal of Enology and Viticulture, 16(3): 144158.

Skrede G, Wrolstad RE, Durst RW. 2000. Changes in anthocyanins and polyphenolics during juice processing of highbush blueberries (Vaccinium corymbosum L.). Journal of Food Science, 65(2): 357-364. doi:10.1111/j.13652621.2000.tb16007.x

Tan ES, Abdullah A, Maskat MY. 2013. Effect of Drying Methods on Total Antioxidant Capacity of Bitter Gourd (Momordica Charantia) Fruit. AIP Conference Proceedings, 1571: 710-716.
Taşkın O, Aşık BB, İzli N. 2019. Gilaburu Bitkisinin (Viburnum opulus L.) Meyve, Sap ve Yaprağının Mineral İçeriği. Kahramanmaraş Sütçü İmam University Journal of Agriculture and Nature, 22(2): 178-182.

Taşova M, Ergüneş G, Gerçekcioğlu R, Karagül Ş. 2019. Konvektif ve Mikrodalga Yöntemlerle Kurutulan Kuşburnu (Rosamontanachaixsubsp. Woronovii (Lonacz) Ö. Nilsson) Meyvelerinde Kalite Değişimleri. Anatolian Journal of Agricultural Sciences, 34: 312-318.

Tontul İ, Eroğlu E, Topuz A. 2019. Kırınım Pencereli Kurutma ve Sıcak Hava Akımında Kurutma İşlem Şartlarının Kuşburnu Tozlarının Fizikokimyasal Özellikleri Üzerine Etkisi. Gida / The Journal of Food, 44(1): 1-9.

Wang Y, Li J, Dong L, Wu Q, Li L, Yang H, Su D. 2019. Effects of Thermal Processing Methods and Simulated Digestion on the Phenolic Content and Antioxidant Activity of Lotus Leaves. Journal of Food Processing and Preservation, 43: 110.

Zhu A, Shen X. 2014. The model and mass transfer characteristics of convection drying of peach slices. International Journal of Heat and Mass Transfer, 72: 345-351. doi:10.1016/j.ijheatmasstransfer.2014.01.001

Zielinska M, Sadowski P, Błaszczak W. 2016. Combined hot air convective drying and microwave-vacuum drying of blueberries (Vaccinium corymbosum L.): Drying kinetics and quality characteristics. Drying Technology, 34(6): 665-684. doi:10.1080/07373937.2015.1070358 